\title{
Divine love in the letter to the Romans
}

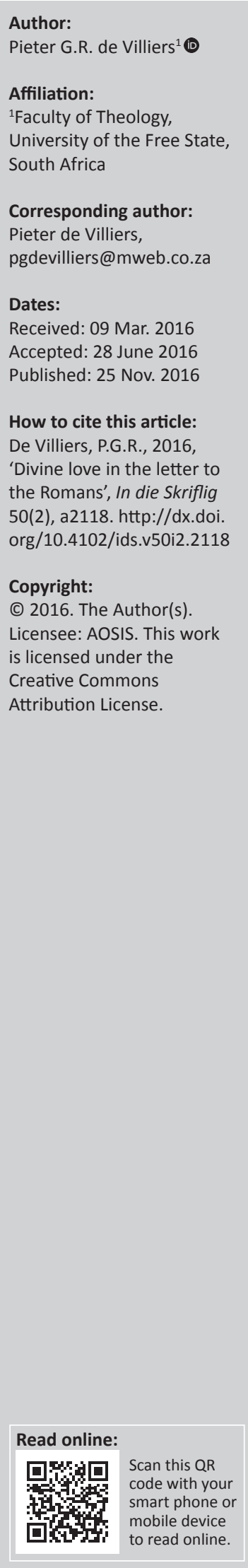

This article investigates divine love in the letter to the Romans from the perspective of love as a key motif in spirituality and in light of spiritual hermeneutics. After a short introduction about the significance of love as a spiritual motif, the article motivates why the notion of divine love is important for understanding the letter to Romans. It challenges existing interpretations of love in contemporary research on Romans that associates it mostly with the relationship between people, neglecting the significant passages in Romans in which love is first and foremost associated with the character and actions of God. In the rest of the article four essential characteristics of divine love is investigated, with attention to its originary, intimate, powerful and self-giving nature. ${ }^{1}$

\section{Introduction \\ Love from a spiritual perspective}

Spirituality, as the Dutch expert, Waaijman, has indicated, has to do with a divine-human relationship that encompasses an on-going process of transformation. ${ }^{2}$ He (Waaijman 2002: 316-351) has further pointed out that an investigation of Scripture reveals that there are four key motifs that characterise this on-going, transformational relationship and, by implication, also of Spirituality. They are awe or fear of God (godliness), holiness, mercy and perfection. These central motifs are closely related and mutually determine each other. In some cases they are also linked with the notion of love. Awe of God is, for example, 'intrinsically connected' with love (Waaijman 2002:318). They determine each other in the sense that love prevents a servile fear of God, whilst fear of God must find its fulfilment in love of God. As Waaijman (2002:316) notes, 'The fear of God takes shape in a reverent life and is perfected in a reverent love' and (2002:318), 'The fear of God leads to love for God'. From Waaijman's description of awe it follows that the divine relationship of God with humanity originates in and is driven by and results in love. It can be accepted that the other key words of mercy, holiness and perfection are also closely related to love.

The significance of love for Spirituality is illustrated most clearly when Waaijman focuses on the transformative nature of the divine-human relationship. For Waaijman, the relation between God and humanity is qualified in a decisive manner as a loving relationship. He (Waaijman 2002:455) develops this insight when he discusses transformation as a key notion in Spirituality that represents the very heart of it. He notes how contemporary authors frequently use 'the word "transformation" precisely in places where they seek to conceptualize spirituality in its essence'. He then analyses the notion in more depth by listing five of its forms. The five, reflecting the 'inner logic of the spiritual way', are transformation in creation (that is from non-being to being in God), in re-creation (that is, from being malformed to being re-formed in God's recreation of man), in conformity (that is, to a transformation model that introduces a person into the divine reality), in love and in glory.

With these observations, Waaijman (2002:455) explains 'transformation' in terms of its 'richly varied semantic field' that has to do with 'form, malform, reform, be conformed and transform'. His first three descriptions of transformation in creation, re-creation and conformity neatly reflect this semantic field of formation. Rather unexpected, though, is Waaijman's following two descriptions of transformation in love and glory, because their names seem unrelated to the 'formation' elements in the semantic field. They draw attention to themselves and to the striking fact that, of all possible words and themes in a religious context, the two descriptions are selected to qualify transformation. First of all, Waaijman notes that love and glory are closely intertwined: Transformation in love is, first of all, about the soul being led into God, but it is also about God 1.With this article I wish to acknowledge the significant contribution of Prof. Fika Janse van Rensburg over a long period of time to the discipline of New Testament Studies in South Africa.

2.Compare the major work of Waaijman (2002:316). This influential publication in the field of Spirituality contains hermeneutical insights that are valuable for biblical scholarship. 
taking up abode in the soul. Love is about the intimate nature of transformation that reflects union and mutuality (cf. further below). Transformation in glory seems to be different from transformation in love in so far as it has to do with what awaits humanity after this life. What waits is, however, illuminated by and in continuity with transformation in love. For Waaijman both the fourth and fifth forms of transformation have to do with love, but it is also about its loving outcomes and ultimate fulfilment. Love remains with humanity without end and characterises human existence in its completeness and fullness. To be transformed in glory is to be and remain in the everlasting condition of love.

Other dimensions of transformative love illuminate its special place in Spirituality, namely love has a divine character. The transformation in love finds its origins in God's love. The transformation in love cannot be effected by someone (Waaijman 2002:472): Humanity is 'overcome by the activity of the fathomless love of God' (Waaijman 2002:470-471, referring to Ruusbroec). This, in turn, illustrates the power of divine love. Divine love for humanity is given without boundaries and restrictions. This, in turn, has further transformative effects: When God touches someone in love, it transforms that person to let go of him- or herself and also to go out in love. In being with the other, those who become part of the loving relationship give themselves completely up to the Other. The one who is loved, is transformed to share or participate in an intimate union of love with the divine. The one who is loved, is transformed to become like the one who loves. 'Love produces such likeness in this transformation of lovers that one can say each is the other and both are one' (Waaijman 2002:469). Mutuality, likeness and intimacy characterise the divine-human relationship. Ultimately, though, love is about a fully integrated and meaningful existence in love. Love represents the highest state attainable in life and brings total fulfilment and tranquillity. "The peculiar nature of transformation in love is that love prompts God and man to rest completely in each other' (Waaijman 2002:469, quoting John of the Cross). Love is about God residing in the soul. 'When the soul is transformed in the Beloved, the Beloved dwells in the soul which he opens up more deeply than the soul can open itself up' (Waaijman 2002:472-474, esp. p. 473).

This discussion of Waaijman (2002:316) flows from the heart of Spirituality, because it draws on profound thoughts on love from some major Spirituality authors like Bernard of Clairvaux, Rumi, Ruusbroec, John of the Cross and the author of the Cloud of Unknowing. But these reflections also have clear biblical roots, drawing on the biblical book, Song of Songs, that was a prominent source to a significant number of mystics to express their understanding of love. This book is part of a reception history of love in Spirituality texts. This history has special relevance and value for the interpretation of Biblical texts.

To value this insight, one needs to consider why and how biblical texts influenced lived spirituality within Christianity over many centuries. Spiritual authors understood and appropriated these texts as their sacred traditions in a special manner. Waaijman (2002:690) described how their approach to the Bible included thoughts on how one detaches oneself from everyday things to entrust oneself to the text; how one realises the inherent thrust and power of the text; how one penetrates the text and learns to savour its deeper meaning; how one's understanding has continuing impact in the practice of life.

An analysis of this approach, also found in lectio divina as a spiritual practice, reveals some typical characteristics and commonalities that can be used to design a model for spiritual hermeneutics. Waaijman, who investigated the praxis of spiritual reading from a phenomenological perspective, systematised his findings under the rubric of 'spiritual hermeneutics' (De Villiers 2008:155-168; 2010: 181-204; Waaijman 2002:689-773). Although his discussion is explanatory of the praxis of spiritual readings rather than prescriptive for interpreting texts, it helps to create sensitivity for and awareness of the spiritual dimensions of biblical hermeneutics. Such hermeneutics can function in a heuristic manner to help biblical scholars recognise unrecognised or neglected aspects of biblical passages. At the same time examples of concrete spiritual readings will provide helpful information to enrich a hermeneutical model for analysing the spiritual nature of biblical texts. As such it feeds into the general field of hermeneutics that benefits from textual studies and explains what is at stake in the process of understanding. This implies that a careful investigation in spiritual readings of love in Spirituality texts and in the Bible has more than mere exegetical value.

Spiritual hermeneutics as a comprehensive field of study reflects on the relationship of the reader with a spiritual text. This relationship can be described in terms of some key material issues. The study of love in biblical texts provides an example of such material insights: it will show how biblical texts incorporated love in their message about the divinehuman relationship and how they interpreted salvific events in terms of love. Love is, however, not an abstract term. It is a dynamical notion, reflecting what the text says about love and how it speaks about love in a loving manner. Scripture reflects attempts to understand the impact of the divine intervention on its readers, both in terms of what they experience, and how they experience it. Waaijman (2002) quotes Augustine who wrote about love as:

the leading principle in the interpretation of Scripture as well as the fruit of the reading process as such. Hence love is not only the alpha and omega of the process of interpretation but, additionally, the aimed-for effect of the entire reading process. (p. 727)

The validity of these remarks will be borne out by more studies on love, not only in the reception history of Spirituality authors, but also by studying the notion of love in biblical texts. This article seeks to contribute to this enterprise by focusing on Paul's understanding of love in the letter to the Romans. 
Romans is a good choice as a source for reflecting on the spiritual nature of a biblical text. Paul's letter to the Romans represents a key moment in his spiritual journey at which he, after his ministry in Asia, wishes to enlist the support of believers in Rome, a significant group in early Christianity, for his on-going mission in the West. In this letter, one encounters Paul as he reflects on the divinehuman relationship in terms of his ministry and the gospel. The letter represents a process of discernment: In the text one recognises a meditative Paul who is taking stock of his own faith experiences in light of his sacred traditions and his encounter with the exalted Christ in order to reflect on the way forward. In this reflection his perspective on love has a programmatic role and place as will be illustrated below.

An investigation of Romans could be affected negatively by its reception history. As is well-known, the letter to the Romans has been associated, in the first instance, with the notion of justification by faith. Where the theme of love has been discussed in research on Romans, it tended to be associated with the human response to the divine act of justification in Christ with special attention to Romans 13-14. It is mostly interpreted from an ethical perspective and therefore as the consequence or outworking of justification by faith. ${ }^{3}$ A good example is to be found in Dunn's comprehensive theology of the Pauline letters. He extensively discusses the important role of love in Pauline ethics, but has a few references to other important dimensions of love (Dunn 2006:658-661). This happens often in discussion about love in the New Testament. The understanding of love is further impeded by the diverse interpretations of love, but also by remarks of some who regard love as a relatively unimportant notion in the New Testament (De Villiers 2008, 2010). ${ }^{4}$

As a result of this kind of focus on love in Pauline ethics, some important dimensions of love do not always receive the attention they deserve. It is therefore especially opportune to investigate love in Romans from a more comprehensive perspective. These relate to love as the intimate union in love that takes shape when believers are touched by a loving God. Although this union of love has consequences for believers, as is indicated by the golden rule in Romans $12-13$, this article focuses on the deeper, more foundational dynamics of love as the origin and face of the divine relationship with humanity. The insights developed in the field of Spirituality, especially in the work of Waaijman, will be used in a heuristic manner in this analysis.

3.Compare Küng (2004:79-84) who's discussion of Barth's view of love focuses on love as a human response to the act of justification. Also compare Sujiin Pak (2008:122-144) for the diverse ways in which the letter to Romans was read by theologians and on page 127-128 for the relatively few references of Luther, Melanchton and Calvin to the motif of love in Romans 5:6-11.

4.Compare Hays (1996:200-203) who argues in some instances that the paucity of references to love in some biblical texts and the meaninglessness of love in contemporary discourses indicate that love cannot be a focal image, although he comments on page 202 that Paul put love to ' comments on page 202 that Paul put love to a "powerful theological use. Södin (1992; 1995) provides an overview of various publications by New Testamen scholars on love in various biblical books, but it is striking how many of these focus on love of the neighbour. In a recent publication on love, Wischmeyer (2015:15) emphasises that love is more than an ethical notion. She writes extensively about love forming an ethical perspective.

\section{References to love in Romans}

Several aspects of love illustrate its special place in the letter to the Romans. It is striking, for example, that one of the very first references to love is found at the beginning of the letter, thereby setting the tone for what is to follow. Romans is the only Pauline letter in which he addresses the readers in the seminal salutation as all those 'who are loved by $\operatorname{God}^{5}(\pi \tilde{\alpha} \sigma \mathrm{v}$

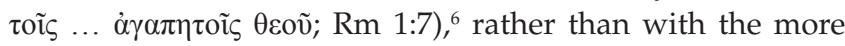
common names such as 'church', 'saints', 'believers' or 'brothers' found in his other letters (1 Cor 1:2; 2 Cor 1:1; Gl 1:2; Eph 1:1; Col 1:2; 1 Th 1:1; 2 Th 1:1). ${ }^{7}$ His readers in Rome are therefore delineated as those who are in a loving relationship with God. The remark is important, not only because of its position in the letter, but also because of the rhetorical function of these opening remarks. Schlier (1977:33) has particularly referred to Romans 1:1-7 as a summary of Paul's gospel so that Paul's characterisation of them as the beloved of God is associated with the essence of the gospel he proclaimed. ${ }^{8}$ Love of God for humanity belongs, according to this programmatic statement, to the heart of the gospel.

With this remark, Paul foregrounds the motif of divine love for humanity. This is underlined when he reminds believers in the rest of Romans 1:7 that love characterises their identity: they are 'called to be saints' ${ }^{9}$ Paul further confirms the loving relationship when he uses the familial, loving description of 'Father' for God at the end of Romans 1:7. ${ }^{10}$ It is a word that describes relationships that are close, tender and intimate.

Addressing the believers in this way in the salutation should be understood in a wider sense within the opening chapters (Rm 1-3) where Paul speaks of people's hateful attitudes and in Romans 1:31 refers particularly to their lack of love. Paul thus links unbelief to a degenerate lifestyle driven by hatred and characterised by a lack of love. Paul considers the identity of the Romans in terms of the loving, kind and compassionate relationship of the divine with them and its transformational impact. His letter spells out to them how the divine love incorporates them into a community in which they share certain privileges and responsibilities with others

\footnotetext{
5.Lohse (2003:69) and Dunn (1988:19) do not comment on the unusual description of the Romans as the beloved. Dunn adds that the adjective indicates a 'more established relation' that is characteristically Jewish and thus distinguishes it from a general pagan description of people as loved by God.
}

6.Paul is clear when he speaks about humanity's love for God as is illustrated by Romans 8:28.

7.Schlier (1977:31) draws attention to the more explicit way of describing believers as loved by God in 1 Thessalonians 1:4;2 Thessalonians 2:13 and Colossians 3:12. These references are not found in the salutations of the letters.

8.Schlier (1977:33) does not develop the motif of love in these comments on the meaning of the prologue.

9.Love and calling are also linked in Romans 8:28.

10.According to Dunn (1988:25) 'Christians are now embraced within God's fatherly care hitherto most fully expressed in reference to Israel'. The notion of Father has become controversial as a result of gender studies and its critique of patriarchy thereby raising consciousness for the problem of male language in the Bible and the way in which it may impede spiritual experiences. See however, HamertonKe way in which it may impede spiritual experiences. See however, HamertonKelly (1979:81) for the description of God as Father. He writes that this goes back to Jesus' experience of an intimate relationship with God that made 'father' the appropriate symbol of his existence (Also see Aasgaard (2004:244, 311) who describes siblingship as "a fundamental perspective, noting that "clearly [Pau] wants to create an atmosphere of love 'in connection with this letter'. Balla (2015:210), quoting Lane, links such familial language with intimacy and tenderness. 
who are loved by God. ${ }^{11}$ It is the love of God and their resultant life of love that distinguish them from an existence without God.

In light of these opening remarks, it comes as no surprise to discover that the letter refers to love in at least 15 other places (Rm 5:5, 8; 8:28, 35, 37, 39; 9:13; 12:9-10; 13:8, 10; 14:15; 15:30). What is also important is that Paul refers to it at seminal points in the unfolding argument. It has been pointed out above that scholarly discussions of love in Romans often focus mostly on its ethical use in chapters 12-13, even though the repeated references reveal that love is mentioned more often in Romans 5-8 than in the later parts. Of special importance is that love is mostly associated with the divine in these earlier parts. When, in the heart of the letter (Rm 8:28-39), Paul speaks about the life through the Spirit and the expectation of the future glory, he ends with an extensive passage on love, arguing that the divine love works for the good of those whom God loves (v. 28). He concludes this powerful section again with remarks about God who loved humanity ( $\mathrm{Rm} 8: 37)$ and that this love is so powerful and enduring that nothing will separate humanity from it (v. 38-39). After an intricate argument about the future of Israel (Rm 9-11), Paul resumes his reflection on love. It is only in Romans 12-13 that the emphasis is more on love as the hallmark of the believing lifestyle. The above overview shows that Paul considers love from a much wider theological perspective than merely the ethical and that he characterises the spiritual identity of the faith community in terms of God's love for them.

These explicit references to love are not the only ones in the letter to the Romans. Often analyses of love in Romans, and, for that matter, in the rest of the New Testament, fail to account for the linguistic insight that words do not have meaning, but meaning is represented by words (Louw \& Nida 1988:288-296). The centrality of love in the Pauline thought is even more striking when one considers that love is depicted not only by the conventional words for love in his letters, but especially from other words belonging to the semantic field of love. ${ }^{12}$ The central place of love in his letters stands out even more when Louw and Nida's semantic field of love, affection and compassion is taken as a guideline. ${ }^{13}$ An example of one such designation is the notion of 'brothers' that is prominent in the Pauline letters. ${ }^{14}$ It is not possible to trace the general use of this term in the Pauline letters here,

11. Compare Hays (1996.196) for the importance of community in the sphere of moral concern. His remarks are, mutatis mutandis, also true for theology and spirituality and, for that matter, for love in the letter to the Romans (cf. further below).

12.Romans 12:10, for example, uses $\varphi \imath \lambda \alpha \delta \varepsilon \lambda \varphi \underline{\alpha} \alpha$ as word for love. Love is, as has been pointed out briefly above, also better understood when it is compared with the semantic field in which the lack of or the contrast to love is expressed. This happen when Paul speaks of those people who suppress the truth by their wickedness (Rm $1: 18)$ by depicting them through various words as unintelligent, faithless, implacable and unmerciful (e.g. Rm 1:31). Among these words is the description

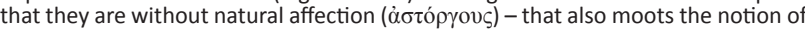
love.

13. Hays' remarks (1996:200-203) that love is not a unifying image in the New Testament, should be tested in terms of this insight.

14.This has also been illustrated by the remarks of Luther, quoted above, in which he speaks of the kindness and gentleness of God in Romans 5. Not only other words, but also actions and expressions can be indicative of love. but in his careful study of siblingship in Paul, Aasgaard (2004) aptly observes that:

Above all ... the sibling relationship was associated with love: siblings were expected to display love towards one another ...

Thus, more than other family relationships, the sibling relation was thought to be distinguished by mutual love. (p. 309)

It is also worthwhile to note Aasgaard's remark (2004) that Paul, in agreement with his social context:

alludes again and again to ideas of love, and exhorts his coChristians to attitudes and actions of love towards one another, which, as noted, involved both emotions and practical obligations. (cf. for example pp. 309 and 311)

The impact of this observation becomes clear when one considers that Paul uses 'brothers' as a term of affection at least 18 times in Romans $(1: 13 ; 7: 1,4 ; 8: 12,29 ; 9: 3 ; 10: 1 ; 11: 25$; $12: 1 ; 14: 10(2 x), 13,15,21 ; 15: 14-15,30 ; 16: 17) .{ }^{15}$ Given the fact that Paul speaks of God as a Father who loves believers, it becomes clear how he regards the faith community in terms of a loving group related to each other in an intimate way as a family called into existence by a loving God. Familial terms that express loving relationships in the faith community find their most significant expression in Romans 8:14-17 where Paul refers to those who are led by the Spirit as children of God and who can cry, 'Abba, Father'. Consequently, believers are not fearful, because the Spirit testifies with their spirit that they are God's children.

Love is regarded in both these cases as an essential element of relationships in which Christians live. Having been touched by God in love, they are constantly in a process of growing deeper into this love and of learning how it transforms not only them in their relationship with God, but also in their relationships with others.

\section{The originary nature of love}

The striking use of love in Romans raises the question about its meaning in the letter. Love is not regarded in an abstract manner as a norm or value, but is about the foundational action of God in establishing a relationship with humanity that restores them in the image of God and that motivates, inspires and characterises them to a loving relationship with others. What believers are, what they do and how they relate to others, mirror what God is and does, and how God relates to others. It is a divine quality of God, reflecting an essential characteristic of God as is explained in Romans 5:8 by the reference to God's 'own' love that he demonstrates in that Christ died for people. God is loving in nature. ${ }^{16}$

Paul does not speculate about this divine love merely and only as an aspect of God's character, but writes mostly about its relational character. It is, as Romans 5:8 stresses, a love 'for

15.Beloved or (beloved) brothers for believers are well-known designations in the Pauline tradition (cf. e.g. 1 Cor 10:14; 15:58; Phlp 4:1; 2 Cor 7:1; 12:19; Phlp 2:12; 1 Th 1:4; Rm 1:7, 13; 7:1; 8:12; 10:1; 11:25; 12:1; 15:40; cf. also 1 Tm 6:2).

16.Dunn (1988:256) finds that the expression can mean that God demonstrated Gods' own love 'to us' (with emphasis on God's own love) or that God demonstrated God's love 'for us', that is, for believers. 
us' and therefore about the divine consciousness of humanity, of relating to and caring for them in a concrete and visible manner.

Paul expressly notes that the loving relationship originates with God. God is, in the words of Romans 1:7 and 8:37, the One who 'loved us'. ${ }^{17}$ That humanity receives this love as a divine gift is implied in Romans 1-3 where Paul portrayed the human condition without God as lacking love (cf. the discussion above). His remark that people are justified ( $\mathrm{Rm}$ 5:9), because God loved and reached out to them even while they were sinners (v. 8) confirms this. The divine 'touch' of humanity (Waaijman 2002:316) sets in motion, but also sustains the divine-human relationship. In Romans 8:29 Paul notes that God works for the good of those who love him. Paul carefully avoids any perception that it is the human love for God that merits the good outcomes by adding the phrase 'who have been called according to God's purpose'. It is the calling of God, as it is expressed in the divine grace that saves and protects (cf. Lohse 2003:252). All these emphasises what Waaijman (2002:316) observes about love in general: 'The transformation in love can in no way be effected by the soul itself'.

The originary nature of divine love is further confirmed by Paul's remark in Romans 5:5 that the love of $\operatorname{God}^{18}$ is poured out through the Spirit. ${ }^{19}$ Paul underscores this when he adds that the Holy Spirit is also a gift from God ( $\operatorname{Rm} 5: 5)$. Elsewhere Paul simply writes about 'the love of the Spirit' (cf. Col 1:8), and in Romans 15:30 he calls upon the believers through 'our Lord Jesus Christ, and through the love of the Spirit' ${ }^{\prime 20}$ to strive with him in prayers for himself. The believing community is in the dispensation of the Spirit that is characterised by love. With this remark, Romans continues Paul's use of the contrasting spheres of the Spirit and the flesh that are also found in Galatians 5. This dispensation is a time and a sphere of love. Paul thereby depicts the origins of love in the divine action, but he also underlines that God sustains the on-going presence of love in the community through the Spirit. The Spirit lives in them in the form of love. ${ }^{21}$

Paul emphasises the spiritual and divine nature of love in Romans 15. He wants to inform the community that God, the lover of humanity, is deeply committed to the relationship

17.The language of love in this verse is overflowing as Paul's use of the hupercompound shows (cf. Dunn 1988:506).

18.For this phrase, compare Wilckens (1978:293). He emphasises that it comprises a subjective genitive.

19.The link between the Spirit and love is not unique to Romans. But whilst Paul briefly lists love as the first of the fruit of the Spirit in Galatians 5:22, he speaks more extensively of the relationship between love and the Spirit in Romans 5:5. Lohse (2003:168) draws attention to the unusual image of pouring out God's love. He explains that it is the result of the link between the gift of love with the outpouring of the Spirit as described in Joel 3:1; Acts 2:17 and 10:45.

20.Lohse (2003:401) reads it, with many others, as a subjective genitive: love is given by the Spirit (cf. also Barrett 1962:279).

21.For the concentrated presentation of a number of images, compare Wilckens $(1978: 292-293)$. He refers, for example, to grace that is nothing other than the power of the divine love. At the same time the grace is linked with righteousness. Righteousness consists of the divine grace, because it has become identical with the divine love. with humanity. God will be present in Paul's ministry in Spain (Rm 15:28) among unbelievers (v. 16). He appeals to them in the name of 'our Lord Jesus Christ' and 'the love of the Spirit' to become supporters of this ministry ( $\mathrm{Rm} \mathrm{15:30).}$ His appeal to them to support his ministry is ultimately a loving request of God in Christ. ${ }^{22}$ This concluding appeal in Romans 15:30 to the Roman community to support Paul's ministry reminds one of the opening remarks in which he addressed them as beloved of God (Rm 1:7). In this way the motif of love forms a ring composition in the book as a whole that further underlines its importance. The deepest common bond between Paul and the community is thus linked with the divine love for them all. Love brought their community into existence, inspires them, unites them and brings them to support one another in promoting God's work and in proclaiming through his ministry the divine love to others.

\section{The intimate nature of love}

Paul approaches his relational understanding of love from two perspectives. On the one hand, he observes that everything can be conquered through 'him who loved us' (Rm 8:27): God, through the Holy Spirit, resides in love for humanity. This passage, however, also reveals the other side of the picture: God works for the good of those 'who love

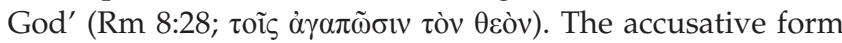
indicates that the love of people for God is under discussion. The passage as a whole therefore illustrates mutuality according to which the one loves the other as the other loves him or her. There is movement in love from God to humanity and from humanity towards God.

Love has another special quality. Waaijman remarks (2002:474) about mutuality that 'The two love movements interpenetrate and open up the space of intimacy' (cf. Col 1:8). This intimacy is also found in Paul's remark about the gift of love through the Holy Spirit. The love of God is, according to Romans 5:5, poured out 'in our hearts' as the innermost being of humanity. ${ }^{23}$ The intimacy transforms humanity to mirror the image of God. The residing of the Spirit in the heart determines the divine-human relationship so that humanity acts like God who love in self-surrender. When believers act lovingly, they act in accordance with their identity as a believing community who live the image of God as the loving, self-giving God (cf. further below).

\section{A powerful love}

The bond of love between God and believers is so intimate that it cannot be broken. The love of God powerfully defies all threats and dangers: when Paul completes his long passage in Romans 8:39 about the loving justification of humanity, he discusses how believers are united in the love of God that is in Christ. The reference to the divine love is

22.Schlier (1977:438) writes some salient remarks about the function of love in this passage.

23.Compare Galatians 2:19-20 where Paul, using traditional christological statements, once again linked with familial language, writes in formulaic, solemn manner about once again linked with familial language, writes in formulaic, solemn manner about
God 'sending out' the Spirit of 'his Son into our hearts' (cf. also GI 3:3, 5-6). Betz (1979:210) explains the 'traditional idea' of the Spirit in the human heart as 'The
(19) 'The $(1979: 210)$ explains the 'traditional idea' of the Spirit in the human hear
heart was considered the organ responsible for the control of the will'. 
part of a highly charged and intense passage about the divine commitment to believers. In it, Paul discusses the salvific actions of God in which God acts on behalf of creation and humanity. Paul's readers, as those who love God (Rm 8:28), thus 'know' that in all things God works for their good. ${ }^{24}$ Paul mentioned this knowing throughout the passage (Rm 8:22 and 28). The culmination is found in Romans 8:38-39 where Paul writes that he is 'convinced' that nothing will separate men and women from the love of God. It is a knowledge that speaks of inner conviction, nurtured by the experience of the divine love. For him the bond with Christ's love is him so strong that nothing can separate believers from it. This reference to the overpowering nature of divine love creates an innermost feeling of certitude, of being loved, of resting in a powerful, loving relationship that will weather all storms.

Paul's powerful language in Romans 8, with its remarkable language of love and certitude, is strong and intense. It illustrates the power of the experience of love and its ability to bring the beloved to complete certitude that nothing can destroy the power of the divine love. Dunn likens the tone of the passage to the majestic chords of a symphony (Dunn 1988:512). ${ }^{25}$ It speaks of God who acts powerfully in many ways. God is for us ( $R m$ 8:31); God did not spare his Son (v. 32); God has chosen (v. 33) and has justified (v. 33) people. He then refers to Christ's death, resurrection and intercession ( $\mathrm{Rm}$ 8:34) before he makes his last remark: 'Who shall separate us from the love of Christ?' Dunn (1988:512) observes that this remark is like the voice of a soloist that rings above even the crescendo of the final chorus as a soaring note of faith. For Paul, the unity with Christ in love has major implications for the lived experience of believers. It is a love that is indestructible, even in the face of all the nameless forces that threaten the Creator's work and purpose. The result is Paul's doxology that reflects an intense experience of peace, of joy and of celebration in and of the divine love that endures and overcomes all threats. Believers 'know' and have the inner awareness that love remains forever.

The power of love and the fact that nothing can separate humanity from the love of God, take on a special meaning in another, equally remarkable passage. Romans 11:28 also speaks of the resting, secure and irrevocable nature of love. This verse is part of a complicated discussion of the relationship between God and the people of Israel. Paul ends this passage with his pronouncement that he does not want his audience to be ignorant 'of this mystery' (Rm 11:25). Paul explains it further to his readers: they should not be conceited about their salvation through faith. Israel too will be saved because of God's covenant with them (Rm 11:26-27; Is 59:20-21; 27:9; Jr 31:33-34). The people of Israel may be enemies of the gospel, but they remain loved by God as far as

24. Lohse (2003:251) refers to many similar pronouncements in texts of late Antiquity but underlines that Paul allocates to it a special place. Of special relevance is that God works for the good of humanity in all things. The context suggests that this refers to eschatological salvation.

25.Lohse (2003:260-261) refers to the passage as a 'doxologischen Lobpreis' [doxological praise] and the 'triumphierende Gewißheit, der die Apostel hervorhebt, in einer klangvollen liturgischen Wendung' [triumphant certainty that the apostle emphasises in a sonorous liturgical phrase].

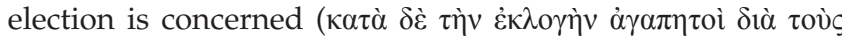
$\pi \alpha \tau \dot{\varepsilon} \rho \alpha \varsigma)$. They too will ultimately experience the divine mercy (Rm 11:30-32). One could say here that not even their hostility to the gospel will separate them from the love of God. As Wilckens (1978:258) notes, Auch als Gottes Feinde bleiben die Juden Gottes Geliebte [Also as enemies of God the Jews remain beloved of God] (cf. Rm 9:5). The divine relationship is not given only to the undeserving and the sinners, but remains a gift even to those who continue in their opposition to this love. This pronouncement is followed in Romans 11:29 by the remarks that 'God's gifts and his call are irrevocable'. The certitude and indestructible nature of the divine love are hereby underlined. So powerful is this love that it cannot be undone by opposition to God. This pronouncement reminds one of Romans 12:14 where Paul asks his readers to bless those that persecute them. Blessing, as an act of love, is in this way not determined by the actions of the other, but is expressed to others despite of their actions.

\section{The self-giving nature of love}

Closely linked with the preceding remarks, is the fact that the divine love is inextricably connected with Christ, as is expressed in Romans 5:8, 'But God demonstrates his own love for us in this: While we were still sinners, Christ died for us' and in Romans 8:39: the love of God is in 'Christ Jesus our Lord'. The latter reference follows after Romans 8:32 where Paul speaks of God who 'did not spare his own Son, but gave him up for us all'. In Romans 8:34 the death of Christ is again mentioned, followed in the next verse by the first reference to the love of Christ ( $R m$ 8:35).

Believers are called to be conformed to the likeness of God's Son (Rm 8:29), which implies that they too should be selfgiving in their love. The nature of this love is thus characterised as self-giving. This is expressed in Romans 12:10 where Paul calls on his readers to 'be devoted to one another in brotherly love'.

Paul's intriguing remark in Romans 12:1-2 is equally informative: having discussed God's mercy in the previous chapters (1-11), he asks believers, by the mercy of God, to offer their bodies as living sacrifices. ${ }^{26}$ Here the notion of transformation is relevant. Believers must be transformed by the renewing of their mind and must find God's will. The living sacrifice and the renewal of the mind are seen in the ethical lifestyle of the community. The language reminds one of the Christological nature of love, spelt out in Romans 5:8, where there is also a reference to self-giving. ${ }^{27}$ To sacrifice oneself is to act lovingly towards others, and later, in Romans 12:2-13:14, he explains in greater depth what the living sacrifice is that is holy and pleasing to God, and that is a spiritual act of worship. In obeying the law of love (Rm 13:8-10), human beings emulate God's character and actions, but they also worship God. Sacrificial service is part of a journey in

26.Compate Wilckens (1978:406) for a discussion of the many interpretations of this passage.

27.Compare the discussion in Schlier (1977:350-358). 
love which means that one shows love concretely toward the brethren (Rm 12:9-13) and even toward enemies and outsiders (v. 14-21). Following God's actions in the sacrifice of the Son, the faith community experiences more of the meaning of love and stands in celebration before the God of love. In loving others, the community is strengthened in love by being brought into the loving presence of the divine. Even their love for others is ultimately about loving God. In this way the love of God for humanity returns to God through serving the community of believers and humanity in general.

There remarks reaffirm the notion of transformation and qualifies it as a transformation in conformity: in Waaijman's words, 'God informs the soul with his grace and conforms it to himself' (Waaijman 2002:472) ${ }^{28}$ Therefore, believers exist to conform to the loving image of God in their relationship with others. ${ }^{29}$ There is an intimate relationship between God and humanity, embedded in and flowing forth from their inner being so that the one who is loved reflects the identity of the one who loves. 'When God inhabits the soul and has transformed it in himself, it becomes transparent to God' (Waaijman 2002:473).

\section{Conclusion}

From the above discussion it follows that love has a deeply spiritual character in the letter to the Romans. The insights developed by Waaijman's analysis of Spirituality have been helpful in enabling us to recognise various dynamics and dimensions of love in the letter to the Romans. Love turns out to be about the loving divine initiative coming to humanity from outside itself. Love is to be found in the life-giving touch of God that transforms humanity powerfully through the Spirit to become as loving as God is. The love of God sustains the believing community in its spiritual journey. It is about an intimate, on-going mutuality that brings people to display more fully the image of God that has been granted to them as a gift in Christ's self-giving action of love. In their mutuality as lovers, God and humanity are one, so that, in Waaijman's words (2002:469), 'each is the other and both are one'. The lovers give themselves up to the other.

Love is about an existence in the Spirit, in faith, that is also characterised by a loving existence in and for the world. As such, love precludes an existence that is focused on itself, but is rather about an inner disposition conformed to Christ that brings about a life of openness, sensitivity and care for others. Love reflects the loving image of God and becomes like God in living a loving existence. Like the outgoing love of God, human love for others is to be found

\section{Compare Romans 8:29 and the discussion below.}

29.Lohse (2003:170) drew attention to Luther's remark that God does not find love in humanity, but creates it. 'Amor Dei non invenit sed creat suam deligibile, Amor hominis fit a suo diligibile. The love of humanity, however, flourishes from the object of love' in actions, in reaching out concretely. It is intensely transformative in nature as it brings people, communities and even enemies together in transformed relationships, but especially brings them into the presence of God. To love others is about loving God, or, even more, about worshipping God.

Love ultimately functions on the very deepest level to let the believing community rest and reside in the divine presence and will. The peculiar nature of transformation in love is that love prompts God and humanity to rest completely in each other in the knowledge that their love is secure and indestructible. Because of this, love displays joy in and celebration of God.

\section{Acknowledgements Competing interests}

The author declares that he has no financial or personal relationships which may have inappropriately influenced him in writing this article.

\section{References}

Aasgaard, R., 2004, My beloved brothers and sisters! Christian siblingship in Paul, T\&T Clark, London. (JSNTSup, 265)

Balla, P., 2015, The child-parent relationship in the New Testament and its Environment, Wipf \& Stock, Eugene, OR.

Barrett, C.K., 1962, A commentary on the epistle to the Romans, A \& C Black, London.

Betz, H.D., 1979, Galatians. A critical and historical commentary on the Bible, Fortress, Philadelphia, PA. (Hermeneia).

De Villiers, P.G.R., 2008, 'Love in the Revelation of John', in H. Blommestijn et al. (eds.), Seeing the Seeker. Explorations in the discipline of spirituality, pp. 155-168, Peeters, Leuven. (Studies in Spirituality 19).

De Villiers, P.G.R., 2010, 'Love in the letter to Philemon', in D.F. Tolmie (ed.), Philemon in perspective. Interpreting a Pauline letter, pp. 181-204, De Gruyter, Berlin, New York. (BZNW 169)

Dunn, J.D.G., 1988, Romans 1-8, Word Books, Dallas, TX.

Dunn, J.D.G., 2006, The theology of Paul the apostle, Eerdmans, Grand Rapids, MI.

Hamerton-Kelly, R., 1979, God the Father, Theology and patriarchy in the teaching of Jesus, Fortress, Philadelphia, PA.

Hays, R.B., 1996, The moral vision of the New Testament: A contemporary introduction to New Testament ethics, HarperSanFrancisco, London.

Küng, H., 2004, Justification: The doctrine of Karl Barth and a catholic reflection, 40th anniversary edn. with a new foreword by Hermann Häring, Westminster John Knox Press, Louisville, KY.

Lohse, E., 2003, Der Brief an die Römer, Vandenhoeck \& Ruprecht, Göttingen. (KEK 4).

Louw, J. \& Nida, E.A., 1988, Greek-English lexicon of the New Testament based on semantic domains, United Bible Societies, New York.

Schlier, H., 1977, Der Römerbrief, Herder, Freiburg, Basel, Wien. (HThK 6).

Söding, T., 1992, Das Trias Glaube, Hoffnung, Liebe bei Paulus: Eine exegetische Studie, Verlag Katholisches Bibelwerk, Stuttgart.

Söding, T., 1995, Das Liebesgebot bei Paulus: Die Mahnung zur Agape im Rahmen der Paulinischen Ethik, Aschendorff, Münster.

Sujiin Pak, G., 2008, 'Luther, Melanchton, and Calvin on Romans 5 and 14. Three reformation approaches to reading Romans', in K. Ehrensperger \& R.W. Holder (eds.), Reformation readings of Romans, pp. 122-144, T\&T Clark, London. (eds.), Reformation readings of Romans,
(Romans through history and cultures series).

Waaijman, K., 2002, Spirituality. Forms, foundations, method, transl. J. Vriend, Peeters, Leuven. (Studies in Spirituality Supplements 8).

Wilckens, U., 1978, Der Brief and die Römer, Benziger, Neukirchener, Neukirchen. (EKK 6/1)

Wischmeyer, O., 2015, Liebe als Agape. Das frühchristliche Konzept und der modern Diskurs, Mohr-Siebck, Tübingen. 